\title{
Mending The Broken Bridges: An Analysis of Familyhood in Zakes Mda's Ways of Dying (1995)
}

\author{
Brightman Makoni
}

Research Scholar

Critical Diversity Studies

University of the Witwatersrand

Johannesburg, South Africa

makbthepro@gmail.com

2367766@ students.wits.ac.za

Abstract

This paper examines South African literature's paradigm shift through Zakes Mda's disruption of the dominant trope of apartheid by his focusing on black ordinary lives in Ways of Dying. The novel foregrounds the broken bridges of love and unity that used to link families before colonisation. Mda demonstrates how the rise of the city engendered the demise of the village where blacks lived as a unified community before migrating to the city whence they sink into individualism. The discussion focuses on family units during the period of death and dying to reveal broken links that happen to have a bearing to black familyhood. The focus of the argument is on how Mda depicts and mends the lost spirit of oneness among the blacks during the final stages of the anti-apartheid struggle and the transition to a democratic South Africa. The discussion highlights a new traditional African community built on forgiveness, care and unity.

Keywords: African Culture, Broken Bridges, Familyhood, City, Village, Migration, Ways of 
Dying

1. Introduction

This paper explores Zakes Mda's depiction of familyhood' as his enterprise to capture the experiences of 'ordinary black lives' in Ways of Dying (1995) during the final stages of anti-apartheid struggle and the transition to a democratic South Africa. The novel answers to Elleke Boehmer laments that "South African English-language fiction calls for some sort of disruption..." (53) and Njabulo S. Ndebele's view that South African fiction is most politically powerful when it explores in the ordinary lives of people new possibilities of understanding and new responses to the struggles they face (Visser 40, qtd in Bheamadu 53). This paper submits that Mda shifts his attention from the 'spectacular' to the reveal the precarity that informs the 'ordinary black lives. The novel captures how family units subsist during the greatest time of death and dying in the late 1980s and early 1990s. The paper's position begins by situating the notion of family[hood] into the broader context of traditional African culture and community values. The argument cascades to the 'particulars of broken bridges of familyhood' and, lastly, to the 'ways in which broken bridges of familyhood' are 'restructured'. The paper closes by a conclusion to particular issues raised in the discussion.

2. Situating 'The Family' into Traditional African Culture

It is impossible to talk about 'family' in the African context without linking it to African culture and community values. Families are regarded as the mainstay of communities where people dwell together. Idang observes that the culture of a people is what marks them out distinctively from other human societies in the family of humanity (97). Mda focuses on South African community which is part and parcel of African culture, and which, according to Idang's supposition, "reveal a wide gap of difference" (97) from that of the coloniser as depicted in the world of the novel. The extraterritorial presence of the communal narrative voice in Ways of Dying (1995) substantiate Mda's focus on familyhood. Patterson posits that 
among African cultures, the family is the most vital institution, and as in all societies, it is the basic social structure within which the individual establishes identity, develops a sense of belonging, and learns the responsibilities to him \herself and his ไher group (3). Swigart glibly postulates that the family is very important throughout Africa whereby families, not individuals, are the building blocks of African society (1).

\section{Familyhood and The Particulars of 'Broken Bridges' in Ways of Dying}

Bheamadu opines that Mda has deliberately not focused on the usual 'White versus Black' confrontation and this relative omission of the white protagonist allows for focus on the African community itself (48).

\subsection{Oppression, Irresponsibility and Abandonment}

In Ways of Dying, the household of Jwara is characterized by 'oppression', 'irresponsibility' and 'abandonment'. The communal narrative voice asserts that Jwara is "a towering handsome giant in gumboots and aging blue overalls, was a blacksmith, and his bellows and the sounds of beating iron filled the air with monotonous rhythms through the day"(25). Jwara, an artisan, "earned his bread by shoeing horses" (25) and creating "figurines"(25). Jwara is not able to live up to the demands of his family. He is oppressive and spends most of his time in his workshop with "that stuck-up bitch, Noria, to sing while he shaped the red-hot iron and brass into images of strange people and animals that he had seen in his dreams" (25). Jwara's family is vividly lopsided, and his wife complains that "You spend all your time with that stuck-up bitch, Noria, and you do not care for your family!" (25).

Jwara has no love and respect to his wife and son, Toloki, who tries to impress Jwara through creative art. Toloki shows him "a picture of a beautiful horse" (28) and is dismissed: "get out of here, you stupid, ugly boy! Can’t you see that I am busy?"(28). Jwara seems to go against Berk's viewpoint that "the family set up plays a paramount role in the development of 
a child as children do not develop into competent adults, simply through the unfolding of their genetic endowment" (qtd in Mafumbate 3). Jwara fails to nurture Toloki into functional adulthood. He is violent and gives Toloki a thorough hiding for the mere reason that "this ugly boy preached in church...[k]icked him in the stomach...[h]e fell down, vomiting blood" (86-87). Toloki runs away from Jwara's oppressiveness "and vowed never to return while his father was alive... making his way to the city to search for love and fortune" (50). Jwara's family disintegrates and Toloki "throughout his long journey of many months he harboured a deep bitterness against his father" (87). Jwara dies a prolonged death which "was completed many years" (92) when Toloki has already "reached the city" (92) His wife deserts him and assumes "a job doing washing for the manager of the general dealer's store" (92) to eke a living as Jwara spends his time seated in his workshop and staring at the figurines. The absence of Noria marks the beginning of Jwara's blue period. The community tries to take care of Jwara but end up abandoning him as he cannot move or talk.

\subsection{Disunity, Patriarchal and Matriarchal Clash}

Xesibe's family foregrounds male versus female power. Twalo contends that Mda sets out to explore the pernicious consequences of both patriarchy and matriarchy (4).While masculine authority remains dominant, Twalo argues, Mda introduces ironical twists to the politics of gender where women define themselves in new and possibly controversial ways (4).That Mountain Woman asserts her dominance over Xesibe, whom she considers "the product of a botched abortion" (62). She goes beyond Xesibe, where she evinces "the razor blades that made people wary of That Mountain Woman" (29). The domineering presence and personality of That Mountain Woman affects both males and females (Twalo 4).She chastises Xesibe who tries to express his displeasure of Jwara's treatment of Noria: "You know, Jwara, I think you spoil that child... You pamper her too much with good things and she is now big-headed that she won't listen to her own father" (29). Xesibe attempts to 
nurture Noria but his wife scolds him: "Hey, you father of Noria! You should be happy for your daughter. You are a pathetic excuse for a father. Or did you want Jwara to buy sweets and chocolate for a thing like you?" Resultantly, "Xesibe was ashamed, and his friends were embarrassed for him" (29) where they are frustrated by the fact that "That Mountain Woman had no respect for our ways and talked with men anyhow she liked" (29). Noria's mother goes against Wiredu's assertion that the family is of unique importance to a child in that it provides a buffer and mediates between the child and the world. That Mountain Woman has a defeatist tendency. Xesibe keeps the dejection to himself and "since that day he never complained again, and Noria continued to receive gifts from Jwara" (29. His wife rubber stamps Jwara's exploitation of Noria as his muse.

\subsection{Poverty, Violence and Alcoholism}

Napu, "a koata, which means that he was uncivilized and uncultured" (71) is a misfit to Noria's family. Noria's parents do not welcome him: "You have shown us how much you don't respect us...your people did not even come to appease us, and negotiate with us, after you had kidnapped our daughter" (67). Napu is parentless and lives below poverty datum level, having "an old grandmother who brought me up" (68) whom he is not able to look after with his meager earnings from a brick-making yard. Napu abuses alcoholand is violent. He pays a visit to his in-laws after Noria's birth to Vutha and he "had a nip of brandy in his pocket" (69) where "an argument ensued" (69) and "they exchanged heated words for a long time" (69) over the naming of Napu and Noria's son. Napu is able to stand up against Noria's mother and he "insisted that his son would be called Vutha...[f]rom time to time he took a swig from his bottle, which we suspected gave him courage to duel so bravely with That Mountain Woman" (70). It is vivid here that alcoholism allows Napu an edge to stand up against That Mountain Woman whom he discovers to be fork-tongued. 
Like Jwara, Napu is not a responsible father and fails to send Vutha to school. Noria couldn't stomach the poverty and "she became increasingly frustrated with their financial situation, which never seemed to improve" (71). Napu begins to womanise and this exacerbates Noria's plight: “One night, almost at midnight, a drunken Napu came home with another woman...[h]e ordered Noria to pack her belongings and vacate the shack" (72). Napu's family is extremely dysfunctional, characterized by intermittent separations: "Although it had been more than two years since Noria was kicked out of her marital home by her husband, she went straight back to the brickyard shack, pushing her overloaded wheelbarrow, and followed by Vutha" (76). Noria violently confronts Napu to create a space for herself and Vutha: "She kicked the door open, and found a woman cooking the evening meal on a primus stove...[w]oman, I am back in my house...[y]ou collect your rags and go!" Noria takes into the shoes of her own mother, That Mountain Woman's domineering character.

Napu varnishes from the brickyard shack and goes to the city with Vutha with all their paltry belongings when Noria has gone to attend the funeral of her mother. Napu exploits his own son Vutha; using Vutha as a begging instrument to get money from well-wishers which he spends in his drinking spree. Napu's irresponsibility as a father figure forces him to chain Vutha and goes for some days to his usual beer drinking carousal. Napu returns after dogs have devoured Vutha to death, and later commits suicide. Without Vutha Noria is a "broken woman who had lost everything that meant something in her life" (79). In this quagmire, Noria "decided to go to the city, to start a new life" (79). This marks the disintegration of Noria's family and her detachment from his father and the village at large. Napu dies in the city away from the village where his grandmother is never heard of.

3.4 Migration, Wealth and Amnesia 
Nefolovhodwe is a married man with a "wife and nine children" (104) to look after. He "used to be the poorest of the three friends"(103) and "had learnt carpentry skills in his youth when he worked in town" (103) but "was barely surviving" (103) from that kind of business, unlike Jwara who "was not doing too badly in his smithy" (103)and "Xesibe was doing well in his farming ventures and in animal husbandry" (103). Business in the village is too low for Nefolovhodwe until "a man from the city visited the village one day" (103). This man sets in motion Nefolovhodwe's migration from the village to the city: "You know, Nefolovhodwe, you are satisfied with living like a pauper here...[b]ut I tell you, my friend, you can make a lot of money in the city...[p]eople die like flies there and your coffins would have a good market" (104). Nefolovhodwe - like Toloki and Noria - takes the city as a panacea to his woes.

Nefolovhodwe is encouraged by Jwara to migrate to the city who"warned him to be careful not to get lost in the city" (104) as many people "went to the city and did not come back" (104). The city is associated with amnesia as migrants forget "all about their friends and relatives in the village" (104). Nefolovhodwe soon "established himself as the best coffin maker" (104) and "unlike the village, death was plentiful in the city...[e]very day there was a line of people wanting to buy his coffins" (104). Of interest is the link between migration and Nefolovhodwe's financial transformation: he moves from the "squatter camps" (104) to the "township house" (104) before "he bought a house in one of the very up-market suburbs" (106).

Nefolovhodwe breaks both the barriers of poverty and racial segregation which characterizes the colonial world of the novel. Nefolovhodwe transmogrifies himself and begins to lead a lavish life. He develops amnesia where wealth engenders his dissociation with his entire family, friends and the village. Nefolovhodwe begins to associate with young and attractive woman of the city who are "tall, thin girl, with straightened hair, red lips and 
purple eyelids, and a face that looked like that of the leupa lizard" (110). Nefolovhodwe's amnesia is testified by his encounter with Toloki in the city:

And who are you, young man?

\section{I am Toloki}

Toloki? Who is Toloki?

Toloki, sir. The son of your friend, Jwara

Well, I don't remember any Toloki. What do you want here? (107).

Nefolovhodwe treats Toloki with a cold hand and offers him the job of going "to the cemeteries only after funerals where a Nefolovhodwe [De Luxe Special] has been used... [I] want you to catch all those undertakers who are making illicit profits from my sweat" (108). Nefolovhodwe is callously offers Toloki a tedious and dangerous task to perform, where Toloki comes close to being murdered after intercepting the undertakers at one of the cemeteries. Nefolovhodwe dismisses Toloki and "he was a very bitter young man...[w]ent back to his shack and locked himself inside while he thought very hard about what to do next" (110). The ill-treatment teaches Toloki of 'new ways of living' and subsequently, "the concept of a Professional Mourner was born” (111).

4. Ways in Which 'Broken Bridges of Familyhood' Are Mended in Ways of Dying

\subsection{The Communal Narrative Voice}

Having highlighted the nitty-gritties of the 'broken bridges' of familyhood, the discussion is now shifting attention to the ways in which Mda 'mends' these 'disintegrated links'. The dominance of the 'communal voice' in the story arrows to the resuscitation of 'familyhood'. Mafumbate observes that in the African traditional family, the community is the custodian of the individual; hence the individual has to go where the community goes (7). In the novel, we are told that:

When in our orature the storyteller begins the story, 'They say it once happened...', we 
are the 'they'. No individual owns any story. The Community is the owner of the story, and it tells it the way it deems it fits. We would not be needing to justify the communal voice that tells this story if you had not wondered how we became so omniscient in the affairs of Toloki and Noria. (12)

Mda brings backoneness among the blacks whose sense of unity has evaporated as a result of colonialism. The 'village' in the novel arrows to this sense of traditional African community where black people once lived as a 'family', unlike in the 'city' where blacks lost ties and fall into individualism:

Both Toloki and Noria left the village at different times, and were bent on losing themselves in the city. They had no desire to find one another, and as a result forgot about the existence of each other. (12)

The city represents the destructive force of familyhood in the novel. The pervading communal narrative voice indicates Mda's mending of the broken bridges of unity and love that once characterized blacks as "traditional life was characterized by brotherhood, a sense of belonging to a large family and by groups rather than individuals" (Fosteret al. qtd in Mafumbate 7). Urbanisation in the novel results in the 'death' of the village as people migrate from the village to the city. The communal voice's use of the plural pronouns 'we' and 'us' is an indication of Mda's way of attempting to restore the sense 'family' amongst the blacks in the novel.

\subsection{Toloki and Noria's Reconvergence}

Toloki and Noria's reunion after years of separation attests to Mda's way of repairing the broken links of traditional African family. Vutha's funeral provides this turn around where Toloki, as a professional mourner, attends the funeral on a Christmas day and acts as a mediator between a funeral and wedding processions, where none could to give way to each other: 
You must give way!

But we are a procession

We are a procession of beautiful people, and many posh cars and buses, while yours is an old skorokoro of a van, and hundreds of ragged souls on foot

The links of unity, love and compassion between the two groups are broken and they should be resuscitated. There is no longer a sense of oneness that used to define traditional African family where the dead is respected. Toloki notices these 'broken bridges' and "walks to the convertible...[h]e greets the bridal couple, and is about to give them a stern lecture on funeral etiquette, when the ill-humoured driver of the convertible suddenly decides that he will give way after all" (11). Toloki instills a sense of Ubuntu into the wedding group and the driver of the convertible "signals to the other drivers in the wedding procession to park on the side of the road so that the funeral procession can pass peacefully" (11). The presence of Toloki as a professional mourner is of effect in this context, as he represents the healing and reengagement of the black community. Toloki symbolises the re-germinating seed of traditional African family love.

It is due to Toloki's positive presence that Shadrack approaches and informs him that "the mother of the child we have just buried wants to thank you for what you have done" (11).Here, Toloki and Noria reconverge:

Toloki! You are Toloki from the village.

Yes, Noria, it is me. I wanted to see you at the graveyard, but they wouldn't let me get near you.

You can't blame them, Toloki. Ever since my son died, all sorts of people have been pestering us. (12)

Fate reunites Toloki and Noria and they brushed aside their differences, where Toloki considered Noria "a stuck-up bitch" (25) that has ruined Jwara's carrier and amassed the love 
and care that was meant for him. Noria understands how she and other people had ill-treated Toloki back in the village: "What does this ugly child of Jwara want here? Go away, Toloki, go away" (42). Noria subsequently "invites Toloki to come and see her at the squatter camp when the sad business of the funeral is over" (12).

Mafumbate observes that 'living together' and the sense of 'community of brothers and sisters' are the basis and expression of the extended family system in Africa (8). This arrangement guaranteed social security for the poor, old, widowed, and orphaned which is one of the most admired values in the traditional African socio-economic arrangement (Mafumbate8). In the novel, Toloki feels pity upon learning of Noria's homelessness where she "explains that after killing her son, they came and petrol-bombed her home...[s]he fled with only her clothes on her back" (43). Toloki offers Noria a hand: "I shall help you to rebuild, Noria" (44). The duo erects Noria's shack "through the night, constructing what Toloki feels is going to be a masterpiece" (49). There is a sense of brotherhood and sisterhood between them. Toloki secures the building material for Noria's shack and pays Shadrack who ferries it with his 'old skorokoro van' from the docklands to the settlement. Mda demonstrates African hospitality which is "the extension of generosity, given freely without strings attached"(Ekeke \& Ekeopora, qtd in Mafumbate 2). Toloki and Noria's attachment to each other blossoms to dizzier heights and Noria suggests to Toloki if they can live together:

Perhaps my ears are deceiving me, Noria.

I am quite serious about it, Toloki. We can live together here as homeboy and homegirl.

It sounds a wonderful idea. But I am afraid. What will people say?

What will they say about what? We come from the same world, Toloki. Our story is the same. You are my homeboy. No one else has any business in our affair (96) 
Biko insinuates that Africans, regarded their living together not as an unfortunate mishap warranting endless competition among them, but as a deliberate act of God to make them a community of brothers and sisters jointly involved in the quest for a composite answer to the varied problems of life (qtd in Mafumbate 4). In the novel, Toloki and Noria - the intertwined protagonists- forge their "creative partnership" (166) and begin to explore and teach each other 'new ways of living' in the greatest time of death and dying. Both migrate to the city and subsequently cut ties with their parents. Their experiences are typically the same as and Noria tells Toloki that "we come from the same world, Toloki...[o]ur story is the same" (96).

\subsection{Xesibe and Jwara's Wife's Cohabitation}

The coming together of Xesibe, the widower and Mother of Toloki, the widow, is testament to Mda's way of reconfiguring the broken links of love and togetherness in traditional African family. At the settlement, Nefolovhodwe says:

Your parents are cohabiting! In their old age, they have caused a scandal by moving together. Toloki and Noria look at each other, and burst out laughing. They cannot imagine how it came about that Xesibe inherited Jwara's wife, or Toloki's mother inherited That Mountain Woman's husband, depending on how you look at it (168). The previous marriages of both Xesibe and Mother of Toloki had proved to be incompatible, thus their children - Noria and Toloki - abandon the village, resulting in their families'total disintegration as Xesibe loses Noria and his wife, and Mother of Toloki loses Toloki and Jwara. What else would they possibly do with such circumstances at hand besides to forge a 'new' union? Xesibe fails to co-exist with That Mountain Woman as husband, and wife and Mother of Toloki fails to make do with Jwara, an irresponsible and oppressive figure. Both have given up on, and accepted the demise of their former partners: Mother of Toloki leaving Jwara in his workshop undergoing his 'process of dying' and takes up a job to fend for 
himself, while Xesibe pays "only three times in three years" (79)that That Mountain Woman is bedridden at the hospital before her death.

Similarly, neither of them has control over their children. Their only grievance, according to Nefolovhodwe's word to Toloki and Noria, "is that their children have neglected them, and do not even go to the village to see them"(168). Unexpectedly, their children end up being together just like what their parents back in the village are doing, and Nefolovhodwe is stunned:

My spies told me they saw you holding hands with a woman. At the time, I did not know it was this Xesibe's daughter who used to make people happy in the village. Are you two married, or are you copying your parents? (169).

The fusion of Jwara and Xesibe's families is Mda's way of reconfiguring functional traditional African family built on the ideals of love, unity and accepting each other 'as they are'. There is no doubt that Toloki and Noria can finally convince one another to go back to the 'village' and reunite with their parents after years of detachment. Thus, this points to reconnection of Xesibe and Mother of Toloki’s families.

\subsection{Madimbhaza and The 'Dumping Place'}

Madimbhaza's caring of abandoned children at her "dumping place" (138) is another way in which Mda attempts to restore the traditional African family to its former glory in the novel:

She is an old woman, this Madimbhaza. She lives in a two-roomed shack which is bigger than the usual settlement shack. Many children are playing in the mud outside. Some of the children are on crutches, and some have their legs in calipers. Her home is known as 'the dumping ground', since women who have unwanted babies dump them in front of her door at night. She feeds and clothes the children out of her measly monthly pension. (138) 
Mda demonstrates the symbiotic nature of the traditional African family where Noria is an aide to Madimbhaza and the children. Noria introduces Toloki to her as she considers the tenderhearted woman "the most important person in my life" (138). Madimbhaza symbolises 'Mother Africa' where those burdened and heavyhearted find refuge and peace. Noria "fled" (157) to her 'dumping place' after her shack is hunted down by members of Young Tigers following the horrible murder of Vutha. Madimbhaza stands for the 'mending of the broken bridges' of love and care as "some mothers returned to collect the children after pressure from God" (139). This attests to Mda's enterprise of repairing the 'wounded traditional African family' that has been rendered obsolete, disunited and out of shape by the forces of colonialism.

Rukuni posits that Ubuntu is a trusted, reliable way of building oneself as a person, as a fully human being, in the spirit of fellowship, humanity, and compassion (qtd in Mafumbate 1). Here, Madimbhaza epitomizes the spirit of loving the African race - Ubuntuism - the driving force that unified inhabitants of those communities that existed before colonialism. In this respect, "Toloki learns that for the past fifteen years Madimbhaza has been taking care of abandoned children" (139) and "to find their biological parents, but usually without success" (139). Mda makes use of a character like Madimbhaza to underscore the recapturing of lost African dignity. Such loss of old traditional African ways results in the destabilization of families, especially children that are regarded as the'hub of the future'. Madimbhaza is a unifier of humanity as "some of the children are victims of the war that is raging in the land" (139). Madimbhaza glibly states the motive behind her actions: "All I want to do in life now is to give them a good start and teach them to be good human beings when they grow up...I will die a very happy person if this can be done" (139). In doing this, Madimbhaza lives to Mafumbate's suggestion that children in the family "require direction and delimitation of 
their vast potential to develop into integrated individuals capable of living amicably in their society together with their fellows (3).

\subsection{Nefolovhodwe's Undertaking of Jwara's Assignment}

Jwara 'commissioning' of Nefolovodwe in his dream to fetch the figurines from the village and deliver them to Toloki in the city typifies Mda's attempt to restore broken bridges that linked and unified blacks as one people:

Nefolovhodwe, however, reveals that for the past two weeks or so, Jwara has been visiting him in his dreams... he said that his figurines were suffering. Nefolovhodwe was the only person who could help, by taking them to their rightful owner, namely, Toloki. After all, he had bequeathed them to his only son, and he could not rest in peace in his grave,or join the world of the ancestors, unless the figurines were given to Toloki (170). Mda brings to light traditional African beliefs and customs, where the dead are considered to have great influence on the living, whom they communicate through dreams. Nefolovhodwe's attempts to disobey Jwara's word by focusing on his business and not "to go looking for some stupid figurines in some faraway village he never wanted to have anything to do with ever again" (170) are thwarted by Jwara who "continued to haunt him... [t]hen his fleas began to die...[i]n his nightly visits, Jwara laughed and danced, and warned that more fleas would die if Nefolovhodwe did not do what he, Jwara, was ordering him to do" (170). Jwara's intention is to reunite, through his estate (figurines), with Toloki, his only son, and makes Nefolovhodwe to go back to the village after years of absence, where he "rounded up a few labourers, and proceeded to excavate" (171) the figurines from Jwara's dilapidated workshop and arranges a truck from his base in the city to ferry them to Toloki, the rightful owner. Nefolovhodwe completes the assignment and sternly orders Toloki that "now that I have given you your figurines, please tell your father to stop bothering me" (172). In this 
respect, Nefolovhodwe appears to have recovered from amnesia and is back to his old self. Nefolovhodwe is transformed into a functional figure among his people.

Toloki's eventual acceptance of his father's estate after initial rejection that "I have said that I am not accepting them...[w]hat does my father want me to do with these ugly things?" (172) is an indication of Mda's repairing of the broken bridges that link traditional African family. Toloki appears to have reunited with his after he had disengaged himself from anything to do with him. Toloki's change of mind to accept the figurines is also as a result of Noria's intervention who tries to beat a sense into his head: "Toloki, the figurines are not ugly...[r]emember that my spirit is in them too... and we must never use that painful word - ugly" (172). Nefolovhodwe markets some of the figurines to his friends at gallery and museum where "there might be individual pieces with special features that would make them stand apart" (173) and allow Toloki to sell eximious figurines there.

The presence of the figurines at Toloki and Noria's shack brings the whole settlement to a standstill, as "Toloki is amazed that the figurines give pleasure to the children in the same way that Noria gave pleasure to the whole community back in the village" (174). We see the rediscovery of the ordinary, the link between the past and present, as Toloki and Noria "decide that they will keep one of the figurines in their shack, next to Toloki's roses, to remind themselves where they came from" (175). The figurines point to the birth of a "unified present' as well as the re-emergence of an African community built and anchored on love as "Toloki takes out his cake and onions" (174) and began to "share the cakes with the children" (174). There is an interlacing of the village and the city, and this arrows to the mending of the broken bridges which used to unify the traditional African family. Noria also suggests to "sell" (175) some of the figurines and "take the money to Madimbhaza's dumping ground" (175) or alternatively, to have them remain at their shack so that "the children could laugh whenever they felt like it" (175). Of major interest here is that the two options are of benefit 
to the community rather than to Noria and Toloki. Mda demonstrates the rediscovery of the lost spirit of oneness, of peace and of love that defines black people. In doing so, Mda repairs the broken links of the traditional African family as his focusing on the Black community points to the priorities for the future such as fostering social solidarity and attending urgently to the needs of those most severely hit by apartheid (Samin 25, qtd in Bheamadu 48).

\section{Conclusion}

It is the finding of this paper that Ways of Dying is an epitome of South African literature that breaks away from being confrontational to that which attempts to rediscover the 'ordinary' by focusing on the experiences of the black African lives. The paper underscored how blacks lost their sense of cohesion and the possible ways of rediscovering traditional values that define the black family. The discussion provided the rewriting of the image of Africa and the work suggests the ways in which post-colonial African states can self-define, empower and strengthen communities based on respect, love, compassion and unity. 


\section{Works Cited}

Bheamadu, Nalini. Magic Realism and Images of the Transition in Zakes Mda's 'Ways of Dying'. University of Kwa-Zulu Natal. 2004

Biko, Steve.I write what I like: A selection of his writing. Johannesburg: Picador. 2006.

Boehmer, Elleke. Colonial and Post-Colonial Literature. Oxford and New York: Oxford University Press. 1985.

Ekeke, Charles, E. \& Ekeopara, Chike. A. God's divinities in African traditional religions ontology: A Conceptual and Philosophical Analysis. American Journal of Social and Management Sciences. 1 (2): 209-218. 2010.

Idang, Gabriel, E. African Culture and Values. University of South Africa. Vol. 16, No.2, pp. 97-111. 2015.

Mafumbate, Racheal.The Undiluted African Community: Values, The Family, Orphanage and Wellness in Traditional Africa. Information and Knowledge Management, Vol. 9, No. 8. 2019. DOI:10. 7176/IKM. 2019.

Mda, Zakes. Ways of Dying. Cape Town: Oxford University Press. 1995.

Ndebele, Njabulo, S. Rediscovery of the Ordinary: Essays on South African Literature and Culture. Johannesburg: COSAW. 1991.

Patterson, Ruth. P.African Studies Curriculum Unit: The Cycle of Life in the African Family. Illinois University, Urbana. African Studies Program. 1978.

Rukuni, Mandivamba. Being African. Johannesburg: Penguin Books. 2010.

Samin, Richard. "Burdens of Rage and Grief": Reconciliation in Post-Apartheid Fiction. Commonwealth Essays and Studies 23 (1). 2002.

Visser, Irene. How to live in Post-Apartheid South Africa. Reading Zakes Mda's Ways of Dying. Wasafiri Vol. 37: 39-43. 2002. 